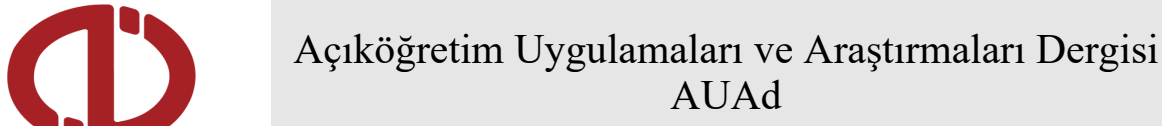 \\ auad.anadolu.edu.tr
}

Gönderim: 05.01.2021

Düzeltme: 18.03 .2021

Kabul: 10.04 .2021

Tür: Araştırma Makalesi

\section{Havacılık Yönetimi lisans programı öğrenenlerinin genel profil analizi ile açıköğretim sistemine ilişkin memnuniyetlerinin ve bağlılıklarının incelenmesi}

\author{
Murat DURALİ \\ Nilgün ÖZDAMAR ${ }^{b}$
}

aMehmet Emin Horoz Mesleki ve Teknik Anadolu Lisesi, İstanbul ORCID: 0000-0001-6167-2976

bAnadolu Üniversitesi, Açıköğretim Fakültesi, Eskişehir ORCID: 0000-0002-0634-5734

\begin{abstract}
Özet
Bu çalışmada Anadolu Üniversitesi İşletme Fakültesine bağlı Havacıllk Yönetimi Lisans Programı 2019-2020 güz dönemi öğrenenlerinin, demografik özelliklerine, kariyer önceliklerine, programı tercih etme nedenlerine yönelik genel profili tanımlanmaktadır. Bununla birlikte öğrenenlerin Anadolu Üniversitesi Açıöğgretim sisteminin sunduğu uzaktan eğitim ve destek hizmetlerine ilișkin memnuniyetlerinin belirlenmesi amaçlanmaktadır. Ayrıca çalıșmada net tavsiye skoru ölçülerek öğrenenlerin eğitime devam ettiği programa ve uzaktan eğitime karşı bağlılık düzeyleri incelenmiştir. Öğrenenlerin demografik özellikleri, eğitim aldıkları programı seçme amaçları ve değerlendirme sonuçları regresyon analizi kullanılarak net tavsiye skorunu ne derecede etkiledikleri ölçülmüştür. Elde edilen sonuçlara göre, öğrenenlerin verdiği cevaplardan uzaktan eğitim sistemine karşı olumlu bir yaklaşımı olduğu ve lisansüstü eğitime de uzaktan eğitim yoluyla devam etme eğilimleri olduğu anlaşılmaktadır. Öğrenenlerin, Havacılık Yönetimi programı için Net Tavsiye Skoru (NPS), 29 çıkmıştır. Bu sonuçta öğrenenlerin Açıköğretim sisteminden memnun olduklarını göstermektedir.
\end{abstract}

Anahtar Sözcükler: Havacılık yönetimi, öğrenen profili, NPS, net tavsiye skoru, açık ve uzaktan eğitim.

\section{Examining their satisfaction and commitment in open education with the general profile analysis of Aviation Management undergraduate program learners}

\begin{abstract}
In this study, the general profile of the students of the Aviation Management Undergraduate Program 2019-2020 fall semester, affiliated to Anadolu University Faculty of Business Administration, regarding their demographic characteristics, career priorities, and reasons for choosing the program is defined. It aims to determine learners' satisfaction with the distance education and support services offered by the Anadolu University Open Education system. Similarly, by measuring the study's net promoter score, the learners' level of commitment to the program and distance education was examined. The learners' demographic characteristics, the goals of choosing the program they studied, and the evaluation results were measured using regression analysis to calculate how much they affect the net recommendation score. According to the results, it is understood from the answers given by the learners that they have a positive approach towards the distance education system, and they have a tendency to continue postgraduate education through distance education. The Net Promoter Score (NPS) of learners for the Aviation Management program is 29. This result shows that the learners are satisfied with the Open Education system.
\end{abstract}

Keywords: Aviation management, learner profile, NPS, net promoter score, open and distance education.

Durali, M. ve Özdamar, N. (2021). Havacılık Yönetimi lisans programı öğrenenlerinin genel profil analizi ile açıköğretim sistemine ilişkin memnuniyetlerinin ve bağl1lıklarının incelenmesi. Açıköğretim Uygulamaları ve Araştırmaları Dergisi (AUAd), 7(2), 64-86. 


\section{Giriş}

Sivil havacılık sektörü 20. yüzyılın başlarından itibaren dünyada en çok gelişen ve teknolojiyle iç içe olan sektörlerin başında gelmektedir. Havacılık sektörü, bünyesinde birçok sistemi barındıran karmaşık bir yapıya sahiptir. Bu yapıyı sürdürebilmek ve geliştirebilmek için yeterli teknik bilgiye sahip, tecrübeli ve nitelikli personele ihtiyacı vardır. Nitelikli personel ihtiyacını karşılayabilmesi içinde uluslararası standartlara sahip eğitim sistemine gereksinim duyulmaktadir.

Her alanda olduğu gibi teknolojik imkanların ilerlemesiyle uzaktan eğitim sistemi de gelişmektedir. Uzaktan eğitim bilginin ve becerinin kazanıldığı, iş bölümü uygulamalarının rasyonelleştirildiği, yüksek kalitede öğretme materyallerinin sunulması maksadıyla teknik yöntemlerden faydalanıldığı ve bu materyallerin farklı yerlerde yaşayan çok sayıda öğrenene ulaştırıldığ etkili kullanıldığg bir yöntemdir (Gökmen vd, 2016; Peters, 1973). Bu firsatlar sayesinde uzaktan eğitimde etkileşim oranı artmakta, zaman ve mesafe kavramı ortadan kalkmakta, bilgiye erişim daha çok kolaylaşmakta ve algı farkı daha da azalmaktadır. Bundan dolayı 21. yy. 'da örgün eğitim ile uzaktan eğitim arasındaki alg1 ve tutumlar artık değişmektedir. Buna bağlı olarak insanların eğitim tercihleri de değişmektedir. Bu değişimden dolayı sivil havacılık alanında da yükseköğretim düzeyinde açık ve uzaktan eğitim yoluyla eğitim verilmeye başlanmıştır. Hatta Covid-19 salgını nedeniyle ICAO(International Civil Aviation Organization) ve IATA(International Air Transport Association) gibi uluslararası sivil havacılık otoriteleri de uzaktan eğitim yoluyla sertifikalandırmaya ve personel eğitimi vermeye başlamıştır. 2015 itibari ile lisans düzeyinde Anadolu Üniversitesi "havacılık yönetimi”, ön lisans düzeyinde ise Atatürk ve İstanbul Üniversiteleri "sivil hava ulaştırma işletmeciliği” programını uzaktan eğitim olarak sürdürmektedir. Bu çalışmada, Anadolu Üniversitesi havacılık yönetimi programı öğrenenlerinin özellikleri, bu programı neden seçtikleri ve tavsiye etme(bağlılık) ölçüleri incelenmiştir.

\section{Araştırma Sorunsalı}

2010’lu yılların sonuna doğru üniversitelerde havacılık yönetimi bölümü sayısı artmakla beraber mezun sayısı da artmaktadır. Bu durum hızlı bir şekilde büyüyen havacılık sektörüne rağmen istihdam konusunda endişelere sebep olmaktadır. Bu kapsamda Sivil havacılık sektörünün nitelikli insan kaynakları ihtiyacının karşılanması için gerekli eğitim politikalarının üretilerek hayata geçirilmesi amacıyla çalışmalarını yürüten Sivil Havacılık Komisyonunun raporları mevcuttur: 
- “Sivil Havacılık işletmeciliği alanındaki kontenjanın 2023’e kadar yeterli olduğu, hatta 2023 yılında ihtiyaç fazlası diplomalı bir gurubun olacağı (SHGM-YÖK Sivil Havacılık Komisyonu, 2015a).”

- “Akdeniz Üniversitesi ve Mustafa Kemal Üniversitesi temsilcileri tarafindan, Türk sivil hava ulaştırma sektörünün ihtiyaç duyduğu kalifiye personel açığının mevcut programlardan rahatlıkla karşılanabileceği, son birkaç yılda çok fazla Sivil Hava Ulaştırma işletmeciliği Programı'nın açıldığı, bundan sonra yeni bölümler açmak yerine mevcut okullardaki standardın ve kalitenin artırılması için çalışılması gerektiği, sivil havacılık alanlarından mezun olan öğrencilerin yeterli donanımla mezun edilemedikleri belirtildi. YÖK'e bu konudaki ihtiyaç analizlerini göz önünde bulundurarak çözüm önerisi sunulması gerektiği, komisyonun amacının bu konularda çalışmalar yaparak çözüm önerileri sunmak olduğu hatırlatıldı (SHGM-YÖK Sivil Havacılık Komisyonu, 2015a).”

- "Niğde Üniversitesi temsilcisi tarafından Türkiye'de sivil havacilıkla ilgili yükseköğretim programlarının açılması, yüksek lisans ve doktora alanlarında eğitim veren kurumların çoğalması ile ilgili konuların görüşülmesi önerildi. Konunun Komisyon çalışmaları arasında yer aldığı belirtildi. İş gücü analizi çalışması yapıldığı ve analize göre hâli hazırdaki bölüm/program sayısının yeterli olduğu hatta bazı bölümlerin fazla olduğu hatırlatıldı. Bölüm/program açılması yerine var olanların kalitesinin arttırılmasının gerektiği belirtildi. Yüksek lisans ve Doktora bölümlerinin de YÖK tarafından desteklendiği hatırlatıldı (SHGM-YÖK Sivil Havacılık Komisyonu, 2015b)."

- "Sektördeki staj kontenjanlarına öğrencilerin yerleştirilmesi bakımından 2015 yılında komisyon tarafından bir çalışma yapıldığı ve hazırlanan HSY (Havacılıkta Staj Yerleştirmeleri) programı ile bu yerleştirmelerin gerçekleştirildiği belirtilmiştir. Fakat aradan geçen zaman içerisinde öğrenci sayısındaki artış nedeniyle staj yerleştirmelerinin SHGM tarafından tek elden yürütülmesinin imkânsız hale geldiği dile getirilmiştir. YÖK ile koordineli olarak yapılan çalışmalarda stajların çok etkin bir şekilde yapılamadığı ve YÖK' ün 8 Haziran 2016 tarih ve 29736 sayılı Resmî Gazete de yayınlanan yönetmeliği gereğince de yükseköğretimde havacılık alanında staj yapma zorunluluğunun kaldırıldığı belirtilmiş ve staj yapma zorunluluğunun artık Üniversite Yönetimlerinin inisiyatifinde olduğu ifade edilmiştir. Bu sebeplere istinaden SHGM Yönetimi tarafından 13 Şubat 2018 tarihinde alınan karar gereğince 2015/1 Staj Genelgesinin yürürlükten kaldırıldığı dile getirilmiştir (SHGM-YÖK Sivil Havacılık Komisyonu, 2018).” 
Yukarıdaki Sivil Havacılık Komisyonu raporları doğrultusunda, nitelikli eleman yetiştirmek için öğrenen gereksinimleri saptanarak eğitimin niteliği arttırılabilir. Öğrenen gereksinimlerini belirlemek ve öğrenenleri tanımak için öğrenen profillerinin belirlenmesine yönelik çalışmalar yardımcı rol oynayabilir. Ayrıca bu gereksinimleri saptamak için öğrenenlerin memnuniyet ve bağlllık ölçüleri bize yol gösterebilir. Yani öğrenenlerin olumlu ya da olumsuz düşünceleri analiz edilerek birtakım iyileştirmeler yapılabilir. Hatta post-fordist bakış açısıyla her programın kendine özgü öğrenen profiline göre öğretim tasarımları ve hedeflerin geliştirilmesi sağlanabilir. Bu tasarımlar sayesinde de eğitimin kalitesi ve niteliği arttırmak mümkün olabilmektedir.

Açık ve uzaktan eğitimde öğrenenler fiziksel bir ortamda bulunmadıkları için öğrenenlerin memnuniyet ve bağlılığını belirleyen en önemli faktörlerin başında destek hizmetleri gelmektedir. Üniversitenin öğrenenlere sunduğu destek hizmetleri; akademik destek, danışmanlık, kaynak desteği, kurum dışı destek, sınav organizasyonu, büro-öğrenme merkezleri, sosyal etkinlikler, mezunlar birliği, sistem tanıtımı, çağrı merkezi, teknik destek, Öğrenme Yönetim Sistemi vs. olarak sıralanabilir.

Bundan dolayı Açıköğretim programlarında Havacılık yönetimi programına kayıtlı öğrenen profillerinin belirlenmesi ve bu programa ilişkin uzaktan eğitim ve destek hizmetlerine ilişkin memnuniyetleri ve bağlılık düzeylerini belirlemek bu çalışmanın amacını oluşturmaktadır. Bu kapsamda çalışmanın araştırma soruları şunlardır:

1. Havacılık Yönetimi Programına katılan öğrenenlerin genel profili nasıldır?

2. Havacılık Yönetimi Lisans Programını öğrenenlerin seçme nedenleri nelerdir?

3. Anadolu Üniversitesi Açıköğretim sisteminin sunduğu uzaktan eğitim ve destek hizmetlerine ilişkin öğrenenlerin memnuniyet düzeyleri nasıldır?

4. Net Tavsiye Skoru ile açıöğretim destek hizmetleri arasında bir ilişki var midir?

$\mathrm{Bu}$ çalışma sayesinde, net tavsiye skorları ile öğrenenlerin demografik özellikleri, üniversitenin sunduğu hizmetler, okuduğu bölümü ve açık öğretimi seçme amaçları arasındaki bağlantıyı keşfetmek mümkün olabilecektir. 


\section{İlgili Alanyazın}

"Üniversite öğrencilerini tanımaya yönelik yapılan profil araştırmaları öğrencinin üniversiteye yerleşmeden önceki eğitim yaşamı, üniversite ve bölüm tercihleri ile ilgili düşünceleri, geldikleri sosyo-ekonomik çevre, içinde bulundukları üniversite yaşamındaki sosyal ve kültürel ortam ile kimi alışkanlıkları gibi durumlar hakkında bilgi veren çalışmalardır. Bunun yanında akademik yaşamdan beklentileri, memnuniyetleri ve geleceğe yönelik hedefleri için yaptıkları çalışmaların belirlenmesi profil belirleme çalışmaları ile ortaya konulmaktadır" (Özdamar, 2015). Bu sayede hem akademik personel hem de bir kurum olarak üniversite kendi öğrencileri hakkında doğru kararlar alabilme imkanına kavuşur. Bu çalışmada karma bir yapıdan ziyade program/bölüm odaklı öğrenci profili belirleme çabası vardır çünkü her programın kendine özel bir öğrenci yapısı mevcuttur.

“Öğrenci profili kavramı, dar anlamda, kuramsal ve imgesel olarak üretilmiş bir bütünlük olan, yani kavramsal bir soyutlamadan ibaret olan öğrencinin ampirik varlığının resmi ya da resmedilmemiş hali olarak tanımlanabilir."(Özsoy, 2004) Bu yüzden eğitimin ne yöne evrildiğini veya hangi eğilimde süreceğini öğrenci profillerinden yordayabiliriz.

"Profil araştırmaları, araştırmanın evrenini oluşturan hedef kitlenin mevcut durumunun çeşitli değişkenler açısından betimlenmesini sağlar. Eğitimin her alanında yer alan bireylerle ilgili yapılan profil araştırmalarında bu bireylerin içinde yer aldığı kültürel bağlam, sosyodemografik faktörler, bireysel özellikler vb. hakkında önemli veriler elde edilmektedir.” (Erkan vd., 2002) Bu yüzden öğrenen profilleri bu bağlamlar, faktörler ve özellikler arasında ilişki kurmamıza yardım edebilir.

Anadolu Üniversitesi Havacılık Yönetimi programına baktığımızda 2015-2016 eğitim yılında açıldığı görülmektedir. Aşağıda belirtilen yıllara ait aktif ve pasif öğrenci sayıları ve öğrencilerin hangi liselerden mezun oldukları gösterilmiştir: 


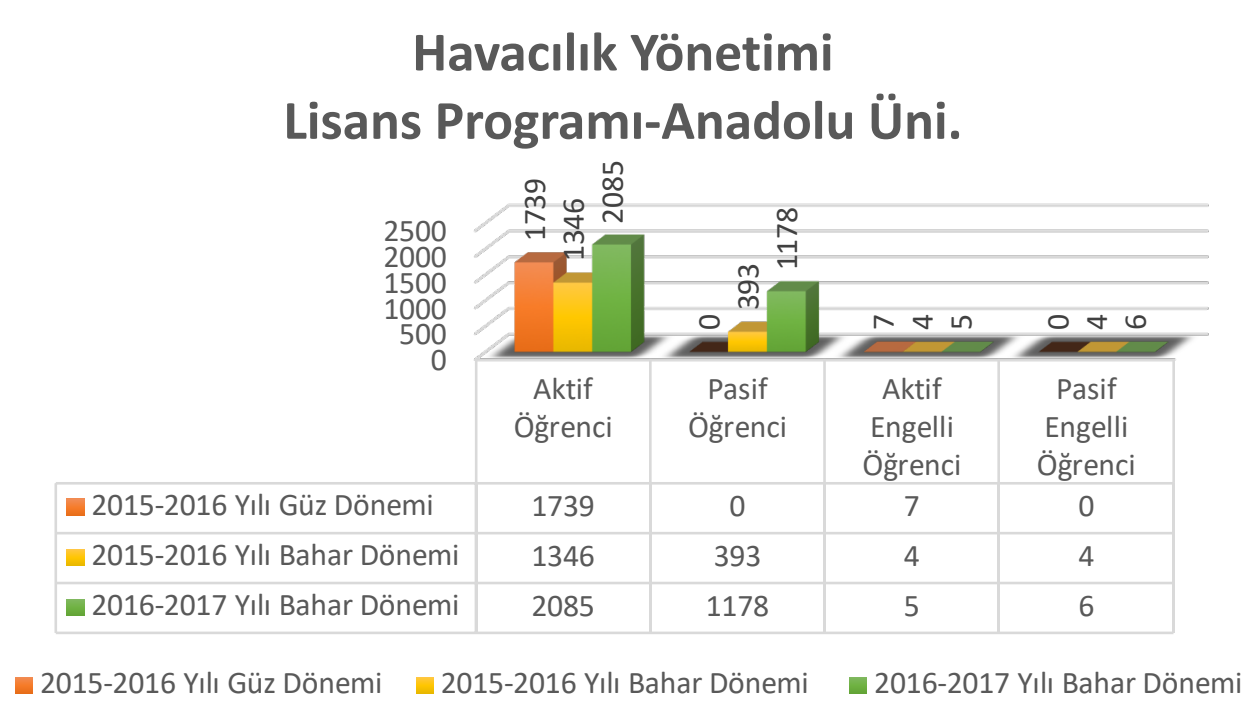

Grafik 1. Anadolu Üniversitesi Havacılık Yönetimi programı öğrenci sayıları(Anadolu Üniversitesi, 2016)

Grafik 1'e göre aktif öğrenci sayısı ile beraber pasif öğrenci sayısının yani kaydını donduran öğrencilerin sayısının da arttığı görülmektedir.

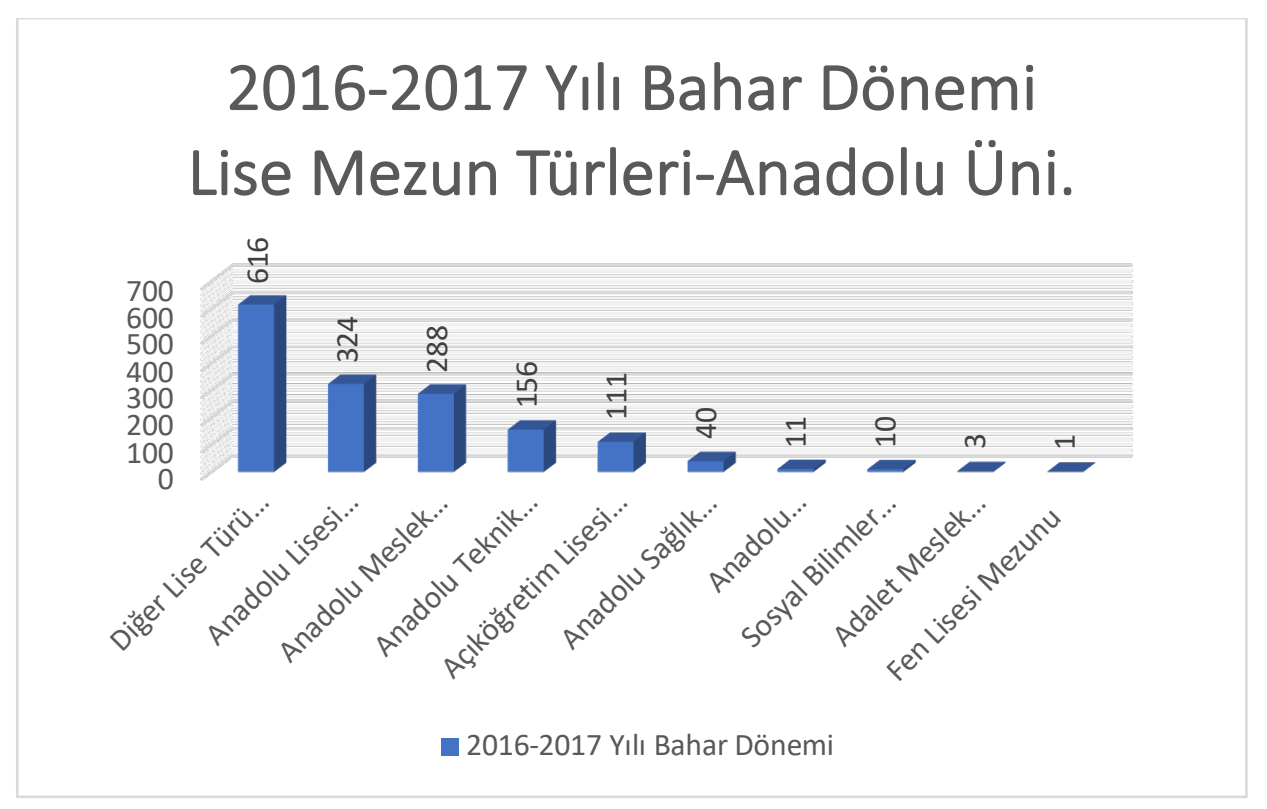

Grafik 2. 2016-2017 bahar dönemi lise mezun türleri(Anadolu Üniversitesi, 2016)

Grafik 2'ye göre öğrencilerin Anadolu ve Meslek Lisesi mezunu ağırlıklı olduğu görülmektedir. 
Aşağıda verilen tabloda ise Anadolu, İstanbul ve Atatürk Üniversitelerinin açıldıkları yıl itibariyle genel kontenjan, genel yerleşen sayısı ve yerleştikleri yıla ait taban puanları verilmiştir:

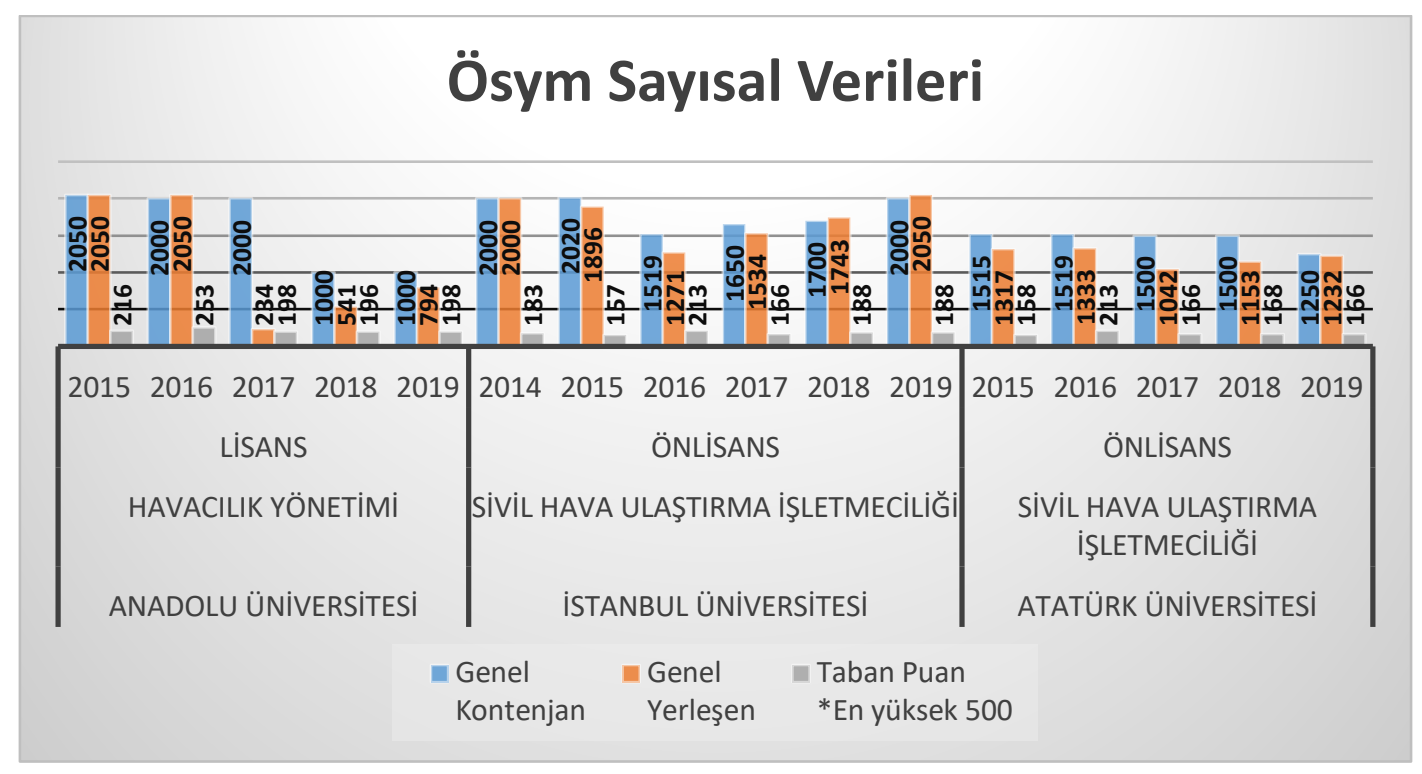

\section{Grafik 3. ÖSYM Sayısal Verileri(ÖSYM, 2020)}

Yukarıdaki grafiklerde Havacılık Yönetimi/Sivil Hava Ulaştırma İşletmeciliği bölümü öğrencilerine ait sayısal veriler yer almaktadır. Bu verilere göre 2015 yılından sonra hem kontenjan sayısında düşüş olmuş, hem de buna rağmen yerleşen öğrenciler genel kontenjanları dolduramamıştır. Anadolu üniversitesinde ise pasif öğrenci sayısı bir önceki yıla göre yaklaşık üç kat artmıştır. Ayrıca öğrencilerin çoğunluğunu diğer lise, Anadolu lisesi ve meslek lisesi mezunudur.

Ayrıca, uzaktan eğitim hizmetini kullananların uzaktan eğitimi tercih etme nedenlerinden bir diğeri ise, zaman ve mekân esnekliğidir. Bağımsız çalışma kuramına göre; öğretmen ve öğrenci görev ve sorumluluklarını birbirinden ayrı yerine getirirler. Bağımsız çalışma programları öğrenenlere öğrenme hedef ve etkinliklerinin belirlenmesinin yanı sıra bireyselleştirilmiş öğrenme süreçlerinin hızı ve düzeninin belirlenmesinde de farklı ölçülerde özgürlük sağlar (Diehl \& Cano, 2018).

Destek hizmetleri içerisinde yer alan kütüphane, rehberlik ve danışmanlık, akademik beceri değerlendirmesi ve geliştirmesi, topluluk gelişimi, birebir destek ve idari hizmetler bulunmaktadır. Bunlar, öğrenme sürecini destekleyen ancak doğrudan ders öğretimini içermeyen hizmetlerdir (Zawacki-Richter \& Anderson, 2014). Uzaktan eğitimde "öğrenci destek hizmetleri”, öğrenen memnuniyeti, motivasyonu, katılımı ve başarısı için kritik öneme sahiptir (LaPadula, 2003). 


\section{Yöntem}

\section{Araștırma Modeli}

$\mathrm{Bu}$ çalışmada konuya uygun olarak, nicel araştırma yöntemlerinden kesitsel tarama modeli (betimsel) kullanılmıştır. Bu model sayesinde tutumlar veya görüşler nicel olarak yorumlanabilmektedir (Creswell \& Creswell, 2017). Bu yöntemin seçilmesinin nedeni, örneklemden elde edilen sonuçların evrene genellenebilir tutum, davranış ve karakteristiğe sahip olabilmesi, ekonomik boyutu ve hızlı veri toplayabilme avantajlarıdır. Geliștirilen bu araştırmada Havacılık Yönetimi programı öğrenenlerinin demografik bilgilerini öğrenmek, NPS skorlarını öğrenmek amacıyla 32 sorudan oluşan bir anket hazırlanmıştır.

$\mathrm{Bu}$ ankette 1-21 arası sorular demografik bilgileri, 22-24 arası sorular kariyer öncelik amaçları, programı ve uzaktan eğitimi seçme nedenleri oluşturmaktadır. 25-27 arası sorular NPS sorularını içermektedir. 29. ve 30. sorular ise 5'li likert tipi olarak destek hizmetleri ve görüş belirtme sorularından oluşmuştur.

\section{Net Tavsiye Skoru}

Fred Reichheld, Bain\&Company ve Satmetrix Sistemleri tarafından geliştirilen NPS(Net Promoter Score), müşteri deneyimi yönetiminde önemli bir gösterge kabul edilmektedir (Wiseback, 2018). NPS, dünyada Fortune 500 şirketleri tarafından yaygın bir şekilde kullanılmaktadır. NPS ölçümlemesi günümüzde şirketler için kritik bir gösterge konumundadır (Wiseback, 2018). İdeal bir NPS skoru sektöre göre farklılık gösterir. Fakat önemli olan bu değerin sıfırın altına düşmemesidir.

Reichheld (2003)'e göre NPS ölçüm aracı, yöneticilerin “iyi” ya da "kötü” demeden sadece kârın peşinden koşma davranışı içinde olmaması gerektiğini, "iyi kâr" elde etmenin tek yolunun da müşterilerin gözündeki performansın doğru ölçülmesi gerektiğinin önemini vurgulamaktadır. $\mathrm{Bu}$ ölçümün asıl amacı; inceleme sonrasında işletmeyi diğer kişilere, müşterilere tavsiye edecek olacak “destekçi müşteriler” (promoters)' in sayısını günden güne artırıp, "tavsiye etmeyen” (detractors) müşterilere odaklanarak onları kazanmaya yönelik çalışmalara yönelmektir (Husgafvel, 2011).

"Uzun dönemde rekabet avantajını elinde tutmak isteyen işletmelerin, hem müşterilerinin gözünde artı değer yaratan mal, hizmetleri sunmaları, hem de işletmeye gönülden bağl1, özverili bir şekilde çalışan "iç müşteri” yaratmaları bir zorunluluk haline gelmiştir. Bunun yanında işletmede çalışan "pasif" (passive) ve "tavsiye etmeyen” (detractors) kişilerin memnuniyetsiz oldukları noktaları tespit etmek ve birtakım iyileştirici düzenlemelerde bulunmak açısından da yöneticilerin bu tür bir ölçüm sistemini kullanmaları faydalı olacaktır” (Demir, 2016). Uzaktan 
eğitimde ise milyonlarca öğrenenin memnuniyetsiz olduğu noktaları tespit etmek ve iyileştirmek bu ölçek sayesinde daha hızlı ve verimli olabilir.

Net Tavsiye Skoru fikrini yükseköğretim bağlamına uyarlarken, iki zorluğun dikkate alınması gerekir ve öğrencileri klasik bir tüketici olarak görmemiz yanlış olur. Birincisi: Ticari şirketlerin aksine, üniversiteler öncelikle büyüme ve kâr elde etmeye çalışmazlar. İkincisi: Öğrenciler klasik anlamda müşteri değildir. Geri alım kararları bunların büyük bir kısmı için önemsizdir, çünkü "satın alma” kararları (yani belirli bir üniversitede çalışmaya başlama kararları) bir defalık bir süreçten kaynaklanır. Yine de NPS konseptinin aktarımının mümkün olduğunu savunuluyor (Schmatz vd., 2015). Bu doğrultuda üniversitenin en önemli rekabet faktörü olumlu bir itibardır (Theus, 1993).

Öte yandan, mezun olduktan sonra sadece çok memnun öğrenciler iletişim halinde kalarak ideal olarak sponsor ve destekçi olarak sadakatlerini ifade edeceklerdir (Hörsch \& Rudinger, 2009). Örneğin; Anadolu Üniversitesi'nde başlatılan kalite elçileri projesinde uzaktan eğitim sisteminden memnun öğrenenlerle iletişim kurulmuş, bu öğrenenlerin daha sonra Açıköğretim programlarının tanıtımında bir elçi gibi görev üstlendikleri gözlenmiş, bu durumunda öğrenenlerin kuruma daha fazla aidiyet duymalarına ve hizmetin değerlendirilmesinde daha paylaşımcı ve katılımcı davranış sergilemelerine yol açtığı belirlenmiştir (Bozkurt vd., 2017).

NPS(Net Tavsiye Skoru)'de uygulanacak ölçüm hesaplaması şu şekilde yapılacaktır:

0’dan 10'a kadar değer verilir. Bu değerlerin sınıflandırılması (Netpromoter, 2020);

- $0-6=$ Desteklemeyenler

- $7-8=$ Pasifler

- $\quad 9-10=$ Destekleyenler

NPS $=($ Destekçilerin Sayısı - Desteklemeyenlerin Sayısı $) /($ Yanıtlayan Sayısı $) \times 100$

\section{Evren ve Örneklem}

Anket, 2019-2020 eğitim yılı bahar döneminde Anadolu Üniversitesi Açıköğretim sisteminde kayıtlı, Havacılık Yönetimi programı öğrenenlerine uygulanmıştır. Çevrimiçi ortamda, gönüllülük esasına göre düzenlenen ankete 320 katılım sağlanmıştır. 


\section{Veri Toplama Araçları}

Araştırmada veriler Microsoft Office Forms aracılığıyla web ortamında toplanmış olup anketten elde edilen verilerin geçerlik ve güvenirliği Tablo 1'deki gibidir.

\begin{tabular}{|c|c|c|c|c|}
\hline \multicolumn{5}{|c|}{$\begin{array}{l}\text { Tablo } 1 \\
\text { Memnuniyet Bildirme Faktör Analizi Sonuç Tablosu }\end{array}$} \\
\hline Faktörün Adı & Soru İfadesi & $\begin{array}{l}\text { Faktör } \\
\text { Ağırlıkları }\end{array}$ & $\begin{array}{l}\text { Faktörün } \\
\text { Açıklayıcılığı(\%) }\end{array}$ & Güvenilirlik \\
\hline $\begin{array}{l}\text { 1. ÜNIVERSİTE } \\
\text { DESTEK } \\
\text { HIZMETLERİ } \\
\text { MEMNUNIYET } \\
\text { DERECELERİ }\end{array}$ & $\begin{array}{ll}- & \text { e-Öğrenme } \\
& \text { Ortamları(Canvas/eKampüs) } \\
\text { - } & \text { Büro Hizmetleri } \\
\text { - } & \text { Çağrı Merkezi } \\
\text { - } & \text { Akademik Danışmanlık } \\
& \text { Hizmetleri }\end{array}$ & $\begin{array}{l}0,917 \\
0,884 \\
0,847 \\
0,832\end{array}$ & 41,931 & 0,855 \\
\hline $\begin{array}{l}\text { 2. UZAKTAN } \\
\text { EĞİTIM } \\
\text { MEMNUNIYET } \\
\text { DERECELERİ }\end{array}$ & $\begin{array}{l}\text { Uzaktan eğitim derslerini } \\
\text { aldığım ögretim görevlisine } \\
\text { internet üzerinden e-posta } \\
\text { ya da özel mesaj ile kolayca } \\
\text { ulaşabiliyorum } \\
\text { - Uzaktan eğitimlerin } \\
\text { kampüste yüz yüze dersler } \\
\text { kadar etkin olduğuna } \\
\text { inanıyorum } \\
\text { Gelecekte de uzaktan eğitim } \\
\text { dersleri almak isterim }\end{array}$ & 0,785 & 28,704 & 0,761 \\
\hline \multicolumn{5}{|c|}{\begin{tabular}{|l|l|} 
Toplam & $\mathbf{7 0 , 6 3 5}$ \\
\end{tabular}} \\
\hline \multicolumn{5}{|c|}{$\begin{array}{rr}\text { Kaiser-Meyer-Olkin Ölçek Geçerliliği } & 0,850 \\
\text { Bartlett Küresellik Testi Ki Kare } & 1046,971 \\
\text { sd } & 21 \\
\text { p değeri } & 0,000 \\
\end{array}$} \\
\hline
\end{tabular}

Öğrenenlerin açıköğretim hizmetleri ile ilgili görüşlerini içeren 7 adet 5 'li likert tipi soru sorulmuştur. Öğrenenlerin bu sorulara verdiği cevapların tutarlılığını test etmek için Cronbach'ın $\alpha$ değeri hesaplanmış ve faktör 1' de 0,855 , faktör 2'de 0,761 olarak güvenilirlik değerlerine ulaşılmıştır. Bu değerler, öğrenenlerin tutarlı cevaplar verdiğini göstermektedir. $\mathrm{Bu}$ iki faktörün(alt boyutun) toplam değişkenliği açıklama derecesi \%70,635’tir. Yukarıdaki tabloda p değeri 0,000 olduğundan değişkenlerimiz analiz yapmaya uygundur. Ayrıca KMO değeri 0,850 olduğundan Tablo 1' e bakıldığında değişkenlerin faktör analizine uygunluğunun mükemmel olduğu görülmektedir.

\section{Veri Toplama Süreci}

$\mathrm{Bu}$ araştırma için kullanılan ankette veriler, 2019-2020 yılı bahar döneminde Anadolu Üniversitesi öğrenci sisteminde(web ortamında) Microsoft Office Forms aracilığıla toplanmıştır.

\section{Veri Analizi}


Anketten elde edilen veriler IBM SPSS Statistics 25 programı aracıllğıyla analiz edilmiştir. Elde edilen veriler regresyon analizi yoluyla belirlenen bağımlı ve bağımsız değişkenler arasındaki ilişkiler incelenmiştir. $\mathrm{Bu}$ değişkenlerin ne ölçüde birbirini etkilediği analiz edilmiştir. Anketin sonunda yer alan "Katkıda bulunmak istediğiniz bir konu var mıdır?" açık uçlu sorusu ise içerik analizi yoluyla çözümlenmiştir.

\section{Etik Konular}

Araştırma için kullanılan anket, uygulanacak üniversitenin etik kurulu onayından geçmiştir. Yapılan anketin içerisinde araştırmanın amacı ve gönüllülük esasları öğrenenlere bildirilmiştir. Ayrıca sağlık, güvenlik, insan hakları, mevcut mevzuat hükümleri, hukukun genel ilkeleri ve etik açıdan ihlal edilmeyeceğinin taahhüdü verilmiştir. Ankette öğrenenlerin cevapları anonim olarak alınmış olup katılımcı gizliliği dikkate alınmıştır.

\section{Araştırmanın Güçlü ve Sınırlı Yönleri}

Yapılan anket üniversitenin izni ile resmî öğrenci giriş sayfasından yönlendirilerek web ortamında yapılmıştır. Bu da örneklemin doğruluğunu arttırıcı bir etkendir. Araştırma, 20192020 eğitim yılında Anadolu Üniversitesi Açıköğretim Havacılık Yönetimi programı öğrencilerinin katılımı ile sınırlıdır.

\section{Bulgular ve Yorumlar}

Bu bölümde anket çalışmasına ilişkin olarak yapılan analizlerin bulguları ve yorumlar sunulmaktadır. Bu çalışmada uygulanan anket, genel bir profil tanımlama aracı olduğu için, öğrenenlere yönelik demografik özellikler, öğrenenlerin programı tercih etme nedenleri, Açıköğretim sisteminin hizmet kalitesine ilişkin memnuniyetleri ve mezun olduktan sonra kariyer planlarına ilişkin sorulardan oluşmaktadır. NPS sorusu sadece "Okuduğunuz bölümü/üniversiteyi bir başkasına tavsiye eder misininiz?" ve "Lütfen kısaca sebebinden bahsediniz" (açık uçlu soru) kısımlarından oluşmaktadır. 
Katılımcıların demografik özellikleri Tablo 2' de verilmiştir.

\begin{tabular}{|c|c|c|}
\hline \multicolumn{3}{|c|}{$\begin{array}{l}\text { Tablo } 2 \\
\text { Katılımcıların Demografik Bilgileri }\end{array}$} \\
\hline \multicolumn{3}{|l|}{ Değişkenler } \\
\hline Cinsiyet & Sayı & Yüzde (\%) \\
\hline Erkek & 209 & 65,3 \\
\hline Kadın & 111 & 34,7 \\
\hline Yaş & Sayı & Yüzde (\%) \\
\hline $18-25$ & 145 & 45,3 \\
\hline $26-33$ & 92 & 28,8 \\
\hline $34-41$ & 59 & 18,4 \\
\hline $42-49$ & 15 & 4,7 \\
\hline $50+$ & 9 & 2,8 \\
\hline Medeni Durum & Sayı & Yüzde (\%) \\
\hline Bekâr & 221 & 69,1 \\
\hline Evli & 99 & 30,9 \\
\hline Öğrenim derecesi & Sayı & Yüzde (\%) \\
\hline Lise & 83 & 25,9 \\
\hline$\ddot{O}$ n lisans & 82 & 25,6 \\
\hline Lisans & 114 & 35,6 \\
\hline Yüksek Lisans & 34 & 10,6 \\
\hline Doktora & 6 & 1,9 \\
\hline Doktora Sonrast & 1 & 0,3 \\
\hline Çalışma Durumu & Sayı & Yüzde (\%) \\
\hline Çalışmıyorum & 110 & 34,4 \\
\hline Emekliyim & 5 & 1,6 \\
\hline Kamu sektöründe çalışlyorum & 75 & 23,4 \\
\hline Özel sektörde çallşıyorum & 118 & 36,9 \\
\hline Serbest çalışıyorum & 12 & 3,8 \\
\hline Aylık net gelir & Sayı & Yüzde (\%) \\
\hline 900-2000 TL & 114 & 35,6 \\
\hline $2001-5000 T L$ & 116 & 36,3 \\
\hline $5001 T L-8000 T L$ & 55 & 17,2 \\
\hline $8001-11000 T L$ & 18 & 5,6 \\
\hline $11001-14000 T L$ & 8 & 2,5 \\
\hline 14001 ve üstü & 9 & 2,8 \\
\hline Kayit Türü & Sayı & Yüzde (\%) \\
\hline Ösym tercihleri ile & 62 & 19,4 \\
\hline Dgs(Dikey Geçiş Sinavı) & 68 & 21,3 \\
\hline Yatay Geçiş & 3 & 0,9 \\
\hline İkinci Üniversite & 187 & 58,4 \\
\hline
\end{tabular}




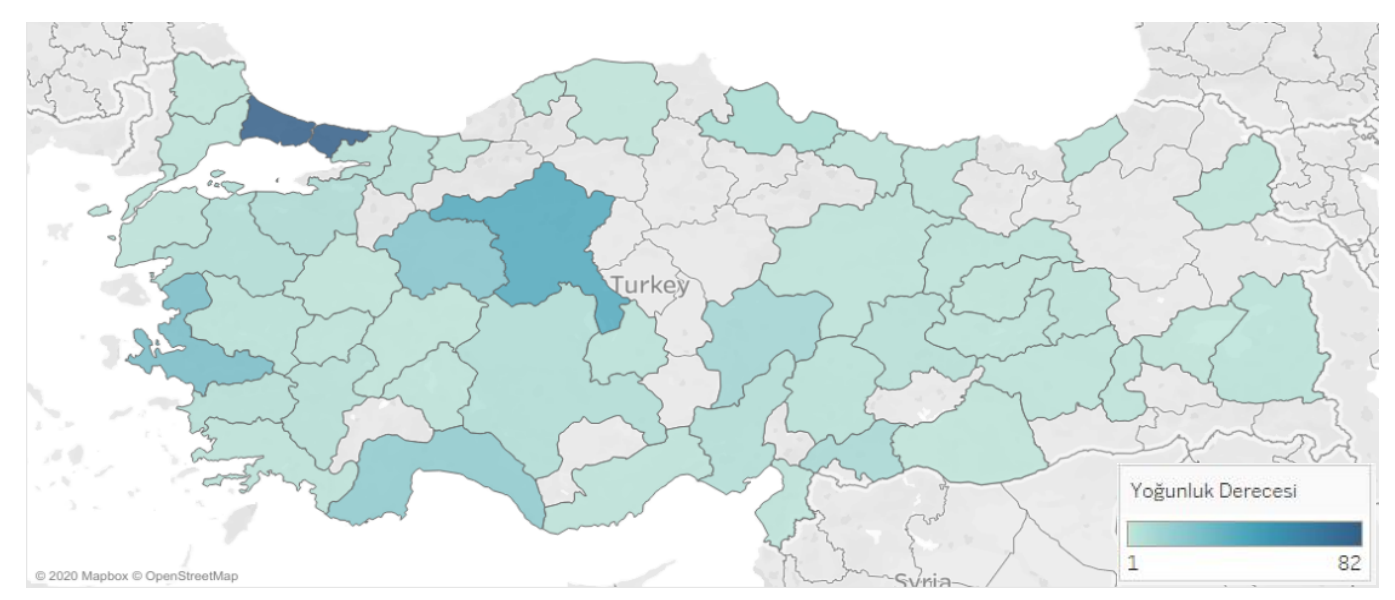

Grafik 4. Katılımcıların İl Dağılım Grafiği

Yukarıdaki şekilde ise katılımcıların ikamet ettikleri illerin yoğunluk grafiğgi verilmiştir.

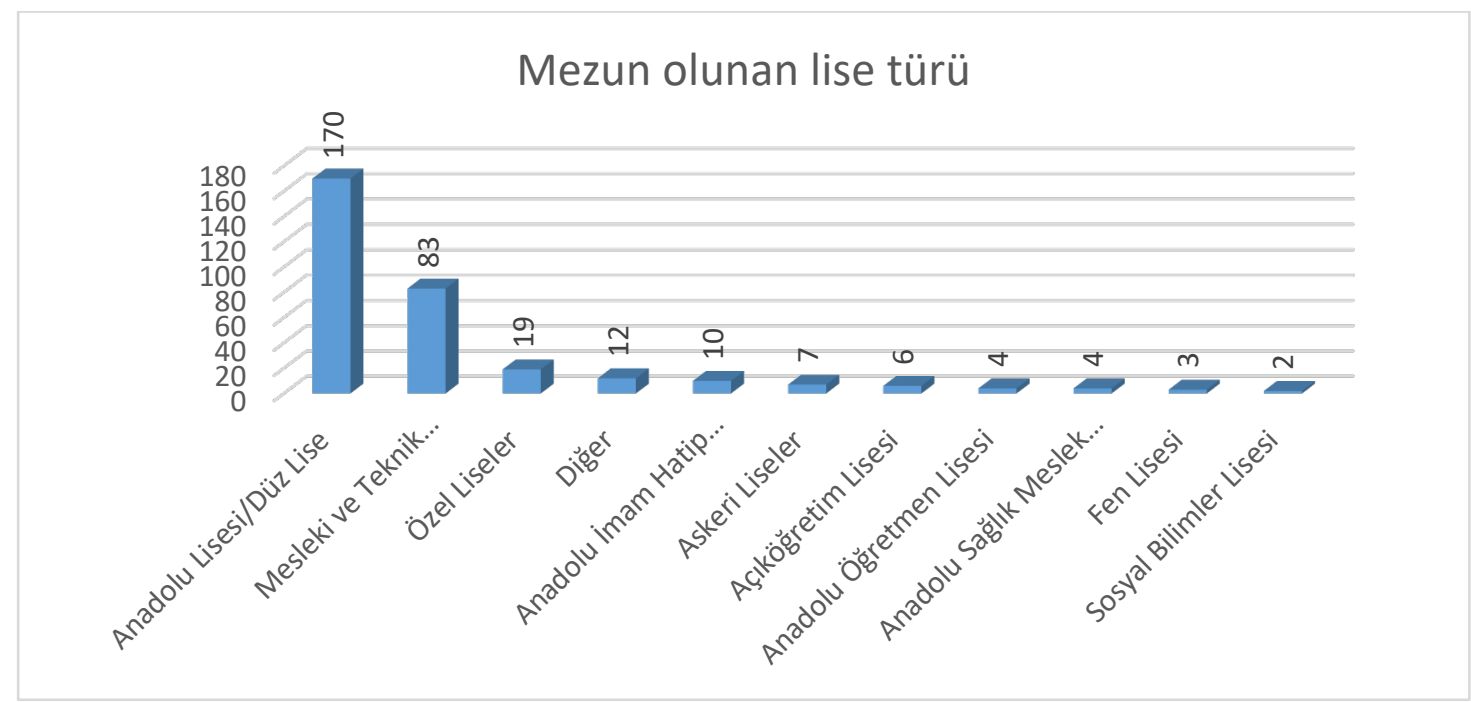

Grafik 5. Katılımcıların Mezun Oldukları Lise Türleri

Şekildeki Grafik 5'e göre mezun oranları grafik 2'deki 2016-2017 eğitim yılındaki veriler ile doğru orantılıdır. Bu program öğrenenlerinin alt yapısını genel olarak Anadolu/Düz Lisesi ve Mesleki ve Teknik Anadolu Lisesi mezunları oluşturmaktadır. Program öğrenenlerine akademik danışmanlık ve kariyer planları bu veriler doğrultusunda oluşturulabilir. 


\begin{tabular}{|c|c|}
\hline $\begin{array}{l}\text { Tablo } 3 \\
\text { Havaculık Yönetimini tercih etmede etkili olan fakt }\end{array}$ & \\
\hline Etkenler & Sayı \\
\hline Havacıllı̆ı geleceğin mesleklerinden biri olarak görüyorum & 213 \\
\hline Kariyerimi geliştirmek & 180 \\
\hline Mesleki konuları öğrenmek & 163 \\
\hline Havacılık alanında bilgi sahibi olmak & 155 \\
\hline Kişisel gelişimimi desteklemek & 148 \\
\hline İstihdam olanaklarının geniş olması & 140 \\
\hline İkinci bir üniversite diploması almak için & 97 \\
\hline Bir işe girebilmek veya yeni bir iş bulmak & 69 \\
\hline Mesleğimi değiştirmek & 66 \\
\hline İnsanlara örnek olmak & 52 \\
\hline İşimde terfi etmek & 38 \\
\hline Emekliliğimde derece atlamak için & 11 \\
\hline Diğer & 9 \\
\hline Rehber öğretmen ya da arkadaş tavsiyesi & 6 \\
\hline
\end{tabular}

Tablo 3' te ankette yer alan 'Bu bölümü tercih etme amacınızda sizi etkileyen seçenekleri işaretleyiniz" kısmı yer almaktadır. Bu verilere göre katılımcıların bilinçli olarak havacılık alanında kariyer yapmak istedikleri için bu programı tercih ettikleri görülmektedir. Bu yüzden akademik danışmanlık ve kariyer planları bu veriler doğrultusunda oluşturulabilir.

\begin{tabular}{|l|c|}
\hline Tablo 4 & \multicolumn{2}{l|}{} \\
Açıköğretim sistemini tercih etme sebeplerinde etkili olan faktörlerin sıklı̆̆ \\
\hline Etkenler & Sayı \\
\hline Çalışıyor olmam & 178 \\
\hline Daha esnek bir yapıya sahip olması(zaman ve mekân) & 170 \\
\hline Devam zorunluluğunun olmaması & 111 \\
\hline Havacılıktaki örgün öğretimden belirgin bir fark görmediğim için & 91 \\
\hline Anadolu Üniversitesinin daha fazla imkanlara sahip olması(Materyal, kaynak, erişim) & 91 \\
\hline Geçmişte kaçırdığım eğitim imkanını yakalamak & 50 \\
\hline Bir üniversiteye girmiş olmak & 29 \\
\hline Gelir düzeyimin başka bir ilde öğrenim görmeme yetmemesi & 27 \\
\hline Ailemle ilgili sorumluluklarım yüz yüze eğitime engel olduğu için & 25 \\
\hline Diğer & 16 \\
\hline Bulunduğum coğrafi konum sebebiyle & 11 \\
\hline Askerliği tecil ettirmek için & 9 \\
\hline Çevremdeki kişilerin açı̈öğretimi tavsiye etmesi & 9 \\
\hline Üniversiteye giriş puanımın buraya yetmesi & 9 \\
\hline
\end{tabular}


Tablo 4' te ankette yer alan 'Açıköğretim sistemini tercih etme sebeplerinde size yakın olan seçenekleri işaretleyiniz" kısmı yer almaktadır. Bu verilere göre katılımcıların demografik bilgilerini destekleyen çalışma durumu ön plana çıkmış ve Açıköğretim sisteminin daha esnek olması, devamlılık zorunluluğunun olmaması gibi avantajları yer almıştır. Bu yüzden akademik danışmanlık ve kariyer planları bu veriler doğrultusunda oluşturulabilir.

\begin{tabular}{|l|c|c|c|c|c|}
\hline $\begin{array}{l}\text { Tablo 5 } \\
\text { Destek Hizmet Kalitesi Memnuniyet } \\
\text { Değerleri }\end{array}$ & $\mathrm{n}$ & Min. & Max. & Ortalama $(\overline{\mathrm{X}})$ & $\begin{array}{c}\text { Standart } \\
\text { Sapma(s) }\end{array}$ \\
\hline & 320 & 1 & 5 & 4,24 & 1,014 \\
\hline $\begin{array}{l}\text {-e-Öğrenme Ortamları(Canvas/eKampüs } \\
\text { vs.) }\end{array}$ & 320 & 1 & 5 & 3,93 & 1,193 \\
\hline -Büro Hizmetleri & 320 & 1 & 5 & 3,49 & 1,412 \\
\hline -Çağrı Merkezi Hizmeti & 320 & 1 & 5 & 3,48 & 1,344 \\
\hline -Akademik Danışmanlık Hizmetleri
\end{tabular}

Tablo 5' e göre yer alan bilgiler incelendiğinde, 320 katılımcının bağımlı(NPS) ve bağımsız(e-Öğrenme Ortamları, Büro Hizmetleri, Çağrı Merkezi Hizmeti, Akademik Danışmanlık Hizmetleri) değişkenlere yönelik sonuçları belirlenmiştir. Ortalama ve standart sapmalara bakıldığında bağımsız değişkenlerin ortalamaları birbirine yakın olup e-öğrenme ortamları (canvas/e-kampüs vs.) memnuniyet derecesi daha yüksek çıkmıştır. Katılımcıların eöğrenme ortamlarındaki memnuniyeti daha fazla, diğer ortamlara yönelik memnuniyetleri olumlu olup birbirine daha yakın olduğu görülmektedir.

\begin{tabular}{|c|c|c|c|}
\hline $\begin{array}{l}\text { Tablo } 6 \\
\text { Regresyon Analizi Sonuçlart }\end{array}$ & & & \\
\hline & $\mathrm{B}$ & SH & $\beta$ \\
\hline Sabit & 3,301 & 0,572 & \\
\hline 1. e-Öğrenme Ortamları(Canvas/eKampüs) & 0,595 & 0,154 & $0,249 *$ \\
\hline 2. Büro Hizmetleri & 0,180 & 0,158 & $0,089 *$ \\
\hline 3. Çağrı Merkezi & $-0,088$ & 0,136 & $-0,051^{*}$ \\
\hline 4. Akademik Danışmanlık Hizmetleri & 0,075 & 0,154 & $0,041^{*}$ \\
\hline $\begin{array}{l}\text { 5. Uzaktan eğitim derslerini aldığım öğretim görevlisine internet } \\
\text { üzerinden e-posta ya da özel mesaj ile kolayca ulaşabiliyorum }\end{array}$ & 0,059 & 0,124 & $0,032 *$ \\
\hline $\begin{array}{l}\text { 6. Uzaktan eğitimlerin kampüste yüz yüze dersler kadar etkin } \\
\text { olduğuna inanıyorum }\end{array}$ & $-0,058$ & 0,131 & $-0,032^{*}$ \\
\hline 7. Gelecekte de uzaktan eğitim dersleri almak isterim & 0,399 & 0,127 & $0,213^{*}$ \\
\hline
\end{tabular}

Tablo 6 incelendiğinde, birden fazla bağımsız değişkenimiz olduğu için Adjusted R Sqaure'e baktığımızda 0,174 değerine ulaşılmıştır. Modelimizde yer alan 7 adet bağımsız değişkenin memnuniyet üzerindeki varyansın \%17,4'ünü açıklamaktadır. Sonuçlara 
bakıldığında $\mathrm{p}<0,05$ olduğu için sig. anlamı değer içermektedir. Bu nedenle çalışmamızda en az bir bağımsız değişkenimiz, bağımlı değişkenimiz olan NPS'yi etkilemektedir. 1. ve 7. bağımsız değişkenlerimiz olan "e-öğrenme ortamları" ile "Gelecekte de uzaktan eğitim dersleri almak isterim", memnuniyet üzerinde anlamlı farklılık göstermiştir. Diğer bağımsız değişkenlerimiz de anlamlı fark bulunamamıştır. İncelenecek olursa e-Öğrenme Ortamlarının(Canvas/e-Kampüs) memnuniyet oranı fazladır. Araştırmadaki katılımcılar Canvas ortamında diğer hizmetlere göre daha fazla memnuniyet duymakta ve gelecekte de uzaktan eğitim dersleri almak konusunda memnun olacaklarını belirtmektedirler. E-öğrenme ortamlarında yer alan 1 birimlik standart sapma değişimi memnuniyet üzerinde yaklaşık \%25'lik bir standart sapma değişimi oluşturmaktadır. Benzer şekilde gelecekte uzaktan eğitim dersleri almak konundaki standart sapma değişimi \%21 olarak kalmaktadır. Pearson koreleasyon değerleri incelendiğinde yüksek değerler bulunamamıştır. Bu nedenle çoklu doğrusallık problemi bulunmamaktadır. Viff değerleri 3'ün altında olması korelasyonun incelenebilir değerler içerdiğini ve doğrusallık problemi içermediğini göstermektedir.

Yapılan analizlerde 1. ve 7. bağımsız değişkenlerin memnuniyet üzerinde anlamlı olduğunu diğerlerinde anlamlı fark bulunmadığını görmekteyiz. Memnuniyeti artırmak için 2,3,4,5 ve 6. bağımsız değişkenler de iyileştirmeler yapılması ve eksiklikleri tespit etmek için yeni çalışmalar yapılması gerektiği anlaşılmaktadır. Tablo 6' da yer alan bilgiler incelendiğinde 320 katılımcının bağımlı ve bağımsız değişkenlere yönelik sonuçları belirlenmiştir. Ortalama ve standart sapmalar incelendiğinde bağımsız değişkenlerin ortalamaları birbirine yakın olup e-öğrenme ortamları(canvas/e-kampüs vs.) daha yüksek çıkmıştır. Sonuç olarak bağımlı değişkenle bağımsız değişkenler arasında ilişki vardır.

\begin{tabular}{|c|c|c|c|c|c|}
\hline \multicolumn{6}{|l|}{$\begin{array}{l}\text { Tablo } 7 \\
\text { Hizmet Kalitesi Memnuniyet } \\
\text { Değerleri }\end{array}$} \\
\hline & $\mathrm{n}$ & Min. & Max. & $\operatorname{Ortalama}(\overline{\mathrm{X}})$ & $\begin{array}{c}\text { Standart } \\
\text { Sapma(s) }\end{array}$ \\
\hline $\begin{array}{l}\text { Okuduğunuz bölümü bir dostunuza } \\
\text { veya iş arkadaşınıza önerme } \\
\text { olasıllı̆ınız nedir? }\end{array}$ & 320 & 0 & 10 & 8 & 2,422 \\
\hline
\end{tabular}

Tablo 7' ye göre yer alan bilgiler incelendiğinde, 320 katılımcının net tavsiye skorunun ortalaması 8 puan olduğu görülmektedir. Net tavsiye skoru ile demografik bilgiler arasında bir farklılık olup olmadığına baktığımızda sadece kayıt türü değişkeninin $p<0,05$ olarak anlamlı sonuç verdiği anlaşılmıştır. Dikey Geçiş Sınavıyla ve yatay geçişle kaydolanların 6-7 arası skoru varken, ikinci üniversite ve ösym kaydı ile gelenler 8-9 arası skora sahiptir. İlk grubun 
skorunun düşük olmasının sebebi açık uçlu sorudan alınan yanıtlarla anlaşılacağı gibi bazı dersleri tekrar almaları ve ağır ders yükü ile karşılaşmaları varsayılabilir.

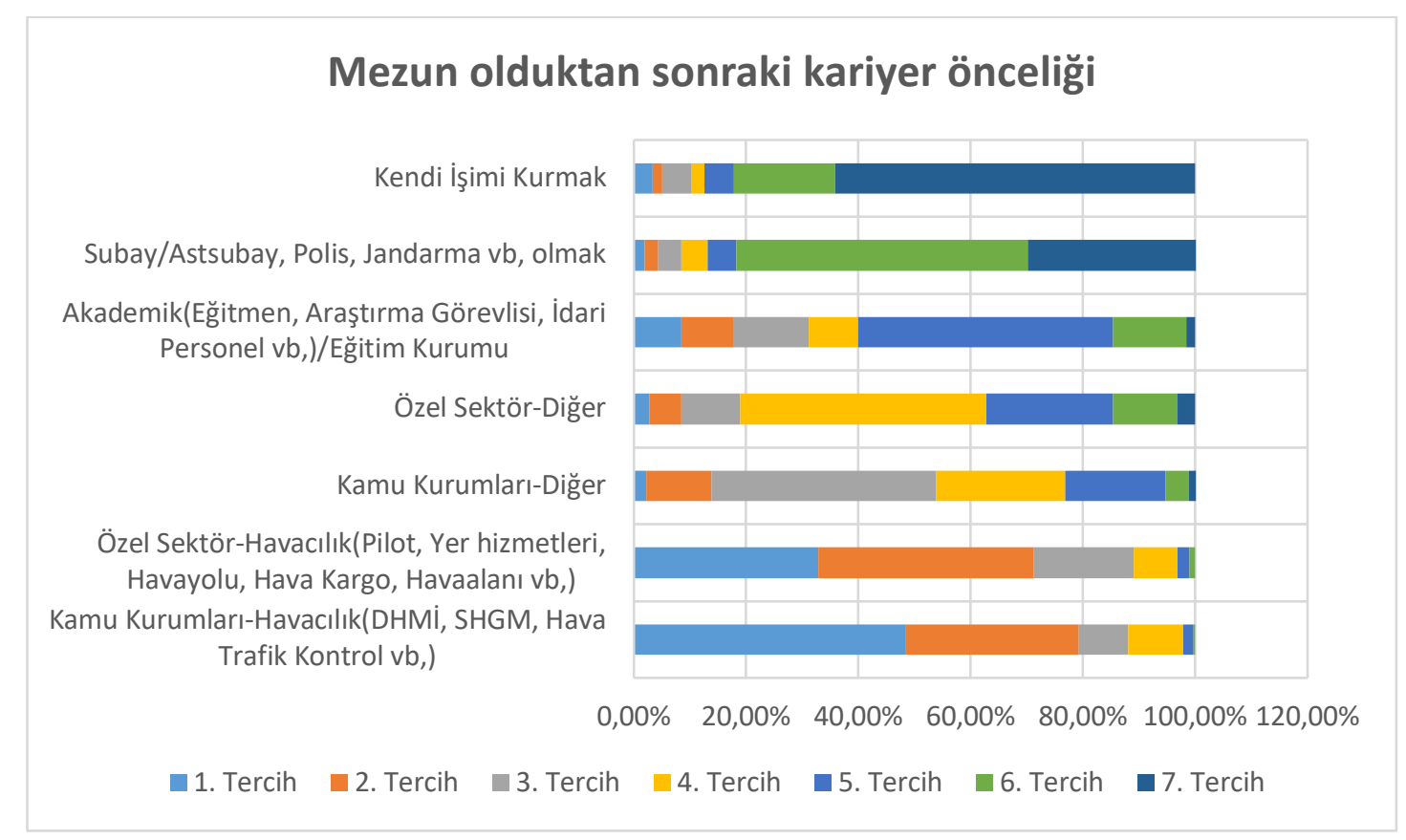

Grafik 6. Katılımcıların Kariyer Öncelik Sıralaması

Grafik 6' da öğrenenlerin mezun olduktan sonraki kariyer öncelikleri yer almaktadır. Buna göre katılımcılar 1. tercih olarak \%48 ile "Kamu Kurumlar1-Havac1lı(DHMİ, SHGM, Hava Trafik Kontrol vb.)", 2. tercih olarak \%38 ile “Özel Sektör-Havacılık(Pilot, Yer hizmetleri, Havayolu, Hava Kargo, Havaalanı vb,)" alanında iş bulmak istemektedir. Bunun için üniversite ders içeriklerinde bu alanlara ağırlık verebilir ya da bu alanlarda öğrenenlere konferanslar, kariyer günleri, uzman kişilerden tecrübe paylaşımları sağlayabilir. Ek olarak akademik danışmanlık ve kariyer planları bu veriler doğrultusunda oluşturulabilir. 


\begin{tabular}{|c|c|}
\hline \multicolumn{2}{|l|}{$\begin{array}{l}\text { Tablo } 8 \\
\text { Katkıda bulunulmak istenen konuların temalandırllması }\end{array}$} \\
\hline Konu & Sayı \\
\hline 1. Staj & 43 \\
\hline 2. Ders İçeriklerinin Güncellenmesi & 11 \\
\hline 3. $\quad$ Kariyer Rehberliği & 10 \\
\hline 4. Havacılık Alanında Yüksek Lisans(Uzaktan Eğitim) Açılması & 8 \\
\hline 5. Akademik Danışmanlık & 4 \\
\hline 6. Kampüsten Yararlanma İmkanlarının Genişletilmesi & 2 \\
\hline 7. Havacılık Alanında Sertifikalı Eğitimlerin Açılması & 2 \\
\hline 8. E-Öğrenme Ortamlarının daha fazla geliştirilmesi & 2 \\
\hline 9. Formasyon Hakkı Tanınması & 1 \\
\hline 10. Meslek Derslerinin Arttırılması & 1 \\
\hline 11. Meslek Derslerinin Canlı Ders Yapılması(Online) & 1 \\
\hline 12. Havacılık Alanında Farklı Bir Bölüm Açılması(Mühendislik) & 1 \\
\hline
\end{tabular}

Anketin sonunda yer alan "Katkıda bulunmak istediğiniz bir konu var mıdır?" açık uçlu sorusuna, 320 katılımcıdan 130 kişi yorum yapmıştır. Bu yorum yapan katılımcıların cevapları, içerik analizi yapılarak 12 başlık altında temalandırılmıştır. Ayrıca temalandırılan konuların frekansları Tablo 8' de gösterilmiştir. Buna göre katılımcıların en çok talepte bulunduğu konu stajdır. Örnek yorumlar:

“Havacılık yönetimi bölümünde isteğe bağlı staj programı olması ve alana yönelik sertifikal programlarında düzenlenmesi alanda ve kariyerde Anadolu Üniversitesi katkısıla yükselmem hem onur hem de değer kazandırır"(Katılımcı82)

"Merhabalar, 12 yıldır hava limanında çalışıyorum. Yolcu hizmetleri harekât ve son olarak ramp bölümünde 7 senedir şeflik yapmaktayım. Ayrıca yer hizmetleri eğitmenliği ve sivil havacılık eğitmeniyim. 2016'dan beri DGR tehlikeli maddeler ĕgitmenliği yapmaktayım. Ĕ̆itmenlik sertifikamı IATA'dan aldım. Üzülerek söylemeliyim ki Tehlikeli maddeler dersinde çıkan sorular tehlikeli madde ile fazla alakalı olmadı̆̆ını gördüm. Tehlikeli madde sinıfları etiketler işaretler acil durum hareket tarzı konular yok. ”(Katılımcı83)

"16 yıldır operasyonel olarak havacılık sektöründe çalışıyorum. Ders içerikleri doyurucu olarak hazırlanmış olmasına rağmen mezun olacakların çalışma ortamları/operasyonel faaliyetler hakkında doyurucu bilgi bulunmuyor. Özellikle 3. ve 4. Sınıf müfredatında sektör-akademi dengesinin kurulamadığını düşünüyorum. Mezun olan ögrenciler temel bilgi düzeyinde yeterli donanıma sahip olacak olsalar da, eğitim geliştirme ve uygulamalar anlaminda daha interaktif ve operasyonel uygulamalar faydalı olacaktır. "(Katılımcı86) 
"Dünya genelinde havacılık dilinin İnilizce olması sebebiyle hazırlanan kitaplar ve kaynaklarda kullanılan terimlerin ya da havacılı̆̆a özel anlamı olan kelimelerin sadece Ingilizce kullanılmasını tercih ederim."(Katılımcı270)

“Açıköğretim sisteminde havacılıkla ilgili staj yapılmamasını bir eksiklik olarak görüyor musunuz?" kapalı uçlu sorusuna evet yanıtı verenler \%69'luk, hayır yanıtını verenler ise \%31'lik kesimi oluşturmaktadır. Ayrıca “Ĕger uzaktan eğitimde havacılık yönetimi yüksek lisans programı açılırsa, eğitim almak ister miydiniz? " kapalı uçlu sorusuna evet yanıtı verenler \%93'lük, hayır yanıtını verenler ise \%7'lik kesimi oluşturmaktadır. Bu da uzaktan eğitime yönelimin devam edeceğini göstermektedir ve Tablo 7' deki açık uçlu soru yanıtlarını destekler niteliktedir.

\section{Net Tavsiye Skoru}

Ankette ölçmek istediğimiz asıl ölçüt olan "'Okuduğunuz bölümü bir dostunuza veya iş arkadaşınıza önerme olasılığınız nedir?" sorusuna yanıt aranmıştır. Net tavsiye skoru $=$ Destekleyen Öğrenen Sayısı - Desteklemeyen Katılımcı Sayısı $x 100$ Toplam Öğrenen Sayısı

Yanıt verenlerin dağılımı:

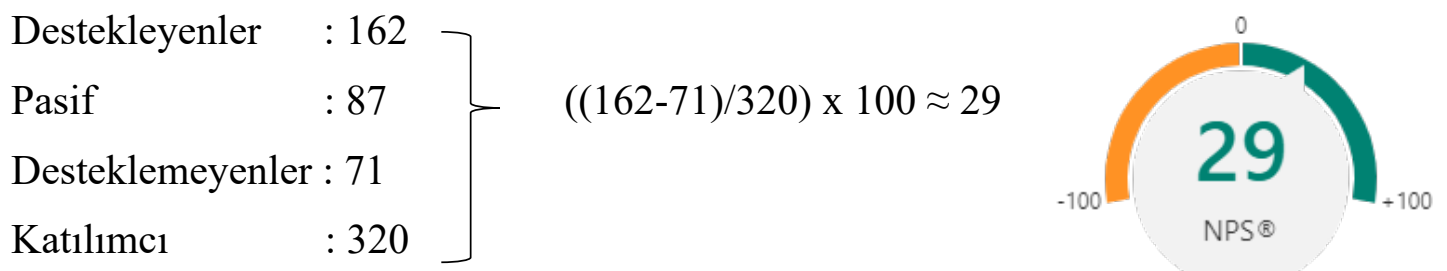

Yukarıdaki veriler doğrultusunda katılımcıların Havacılık Yönetimi programı için Net Tavsiye Skoru(NPS), 29'dur. Sonuç olarak 0(sıfır)'dan büyük değer alması başarılı olduğunu göstermektedir.

\section{Sonuçlar}

$\mathrm{Bu}$ çalışmanın amacı, Açıköğretim programlarında Havacılık yönetimi programına kayıtlı öğrenen profillerinin belirlenmesi ve bu programa ilişkin uzaktan eğitim ve destek hizmetlerine ilişkin memnuniyetleri ve bağlılık düzeylerini belirlemektir. Bu amaçla yapılan anketle, Havacılık Yönetimi bölümü öğrenenlerinin açıköğretim sistemine ve okuduğu bölüme karşı bağl1lık ve memnuniyet derecesi ölçülmüştür. Öğrenenlerin verdiği cevaplardan uzaktan eğitim sistemine karşı olumlu bir yaklaşımı olduğu görülmektedir. Yapılan anketin sonuçlarına göre katılımcıların lisansüstü eğitime de uzaktan eğitim yoluyla devam etme eğilimleri olduğu anlaşılmaktadır. 
$\mathrm{Bu}$ çalışmada Net Tavsiye Skorunu, yükseköğretimde değerlendirme ve kalite güvencesi ihtiyaçlarına yönelik bir memnuniyet ve bağlılık ölçüsü olarak sivil havacılık bölümüne uyarlandı. Bu çerçevede NPS'nin bu yeni bağlam için geçerli olduğu sonucuna varıldı. Ancak NPS tek başına bir ölçüm aracı olarak yeterli değildir. NPS skoru ankette yüksek çıksa da açık uçlu soruya verilen cevaplardan anlaşılacağı üzere bazı konularda ve hizmetlerde eksiklik olduğu anlaşılmaktadır. Bunlar; büro hizmetleri, çağrı merkezi hizmetleri, akademik danışmanlık, öğreten-öğrenen iletişimi ve uzaktan eğitimin etkililiği gibi konulardır. Bu eksikliklerin giderilmesi öğrenenlerin üniversitelerine karşı bağlılık ve memnuniyet ölçüsünü arttıracaktır. Ayrıca eğitim kalitesinin artmasına da katkı sağlayabilir. Böylece üniversitelerin elde tutma (retention) oranları iyileşebilir.

\section{Öneriler}

Yapılan araştırma kapsamında Havacılık Yönetimi programı öğrenenlerinin genel profili ve üniversite hizmetlerinden memnuniyet derecesi yardımıyla Net Tavsiye Skorları(NPS) ölçüldü. Uygulanan anket tüm program öğrenenlerini ve tek bir yarı yılı kapsamıştır. Bunun için gelecek çalışmalarda NPS ölçülürken, öğrenenlerin kaçıncı sınıfta oldukları ve lisans, ön lisans, yüksek lisans seviyeleri dikkate alınması gerekir. Ayrıca üniversitede eğitime yeni başlamış bir öğrenen ile son sınıf ya da mezun öğrenenin değerlendirme bakış açısı farklı olacağından dolayı NPS ölçümü her yıl yapılarak istatistiği tutulabilir. Böylece yıllar arasındaki değişim gözlemlenebilir.

Öğrenenlerin en çok üzerinde durduğu staj konusundaki istekleri ise zorunlu bir staj uygulaması yerine isteğe bağlı staj uygulaması olarak çözülebilir. Ders içeriklerinin güncellenmesi: Katılımcılar burada ders içeriklerinin bir kısmının eski ve artık güncellenmesi gerektiğini bildirmiştir. Kitapların içerisinde havacılık İngilizcesine ağırlık verilmesi ve konuların güncel tutulması sorunu çözecektir. Kariyer rehberliği ve akademik danışmanlık: Açıköğretimde eksikliği en fazla hissedilen konulardan biridir. Bu yüzden öğrenenin eğitim hayatı boyunca hem akademik desteğe hem de kariyer desteğine ihtiyacı vardır. Çağrı merkezi ise bazen bu durumlarda yetersiz kalabiliyor. Bunun için Havacılık alanında webinarlar ya da online konferanslar sağlanarak, örneğin; "nasıl pilot olunur, havacılıkta istihdam alanları nelerdir, alanında uzman kişilerden tecrübe paylaşımı" gibi konularda bu eksiklik giderilebilir. Ayrıca uluslararası seminer ve konferansların da duyurusu yapılabilir.

Son olarak, bu ölçüm diğer üniversite ve programlara da uygulanarak kıyaslama yapılabilir. Böylece NPS ölçümü, üniversite ve eğitim kalitesi ile ilgili çıkabilecek sorunların önüne geçmek için uygulanacak öngörü sistemlerine yardımcı olabilir. 


\section{Kaynakça}

Anadolu Üniversitesi. (2016). Açıköğretim Raporları. A. Bilim. https://acikbilim.anadolu.edu.tr/aosyayinlari.html

Bozkurt, A., vd. (2017). Kitlesel Kaynak Kullanımı ve Yaşamboyu Öğrenenler: Açıköğretim Fakültesi Kalite Elçileri Örneği.

Creswell, J. W., \& Creswell, J. D. (2017). Research design: Qualitative, quantitative, and mixed methods approaches. Sage publications.

Demir, H. C. (2016). Sosyal Paylaşım Siteleri Üzerinden Kullanılan İzlenim Yönetimi Taktiklerinin İstihdam Edilebilirlik Ve Çalışan Net Tavsiye Skoru Üzerindeki Etkisinde Sübjektif Kariyer Başarısının Aracı Rolü; Bankacılık Sektöründe Bir Araştırma

Diehl, W. C., \& Cano, L. (2018). Innovation, Leadership, and Influence. Handbook of Distance Education.

Erkan, S., Tuğrul, B., Üstün, E., Akman, B., \& Şendoğdu, M. (2002). Okulöncesi öğretmenliği öğrencilerine ait türkiye profil araştıması. Hacettepe Üniversitesi Eğitim Fakültesi Dergisi, 23(23).

Hörsch, K., \& Rudinger, G. (2009). Der Net Promoter Score an der Universität Bonn. Forschung und Beratung-Das Zentrum für Evaluation und Methoden, Bonn University Press, Göttingen, 75-88.

Husgafvel, L. (2011). How non-financial customer based metrics are associated with company performance? An analysis of customer satisfaction, customer retention and Net Promoter Score in Telecommunications Industry.

LaPadula, M. (2003). A comprehensive look at online student support services for distance learners. The American Journal of Distance Education, 17(2), 119-128.

Netpromoter. (2020). What Is Net Promoter. Retrieved 04.01.2021 from https://www.netpromoter.com/know/

ÖSYM. (2020). ÖSYS Yerleştirme Sonuçlarına İlişkin Sayısal Bilgiler. https://www.osym.gov.tr/TR,13046/2017.html

Özdamar, N. (2015). Coğrafya ve coğrafya öğretmenliği lisans ögrencilerinin profilleri Gazi Üniversitesi].

Özsoy, S. (2004). Üniversite öğrenci profili: Kavramsal bir çözümleme ve Türkiye’ye ilişkin bazı ampirik bulgular. Kuram ve Uygulamada Eğitim Bilimleri, 4(2), 301-334. 
Reichheld, F. F. (2003). The one number you need to grow. Harvard business review, 81(12), 46-55.

Schmatz, R., vd. (2015). Students as customers. EAIR.

SHGM-YÖK Sivil Havacılık Komisyonu. (2015a). Sivil Havacılık Komisyonu 6. Toplantısı. SHGM.

http://web.shgm.gov.tr/documents/sivilhavacilik/files/pdf/shgm_calisma_gruplari/SH K-6_Toplanti_Raporu.pdf

SHGM-YÖK Sivil Havacılık Komisyonu. (2015b). Sivil Havacılık Komisyonu 7. Toplantısı. SHGM.

http://web.shgm.gov.tr/documents/sivilhavacilik/files/pdf/shgm_calisma_gruplari/SH K-7_RAPOR.pdf

SHGM-YÖK Sivil Havacılık Komisyonu. (2018). Sivil Havacılık Komisyonu 11. Toplantısı. http://web.shgm.gov.tr/documents/sivilhavacilik/files/pdf/calisma_gruplari/11/rapor.p df

Theus, K. T. (1993). Academic reputations: The process of formation and decay. Public relations review, 19(3), 277-291.

Wiseback. (2018). NPS(Net Tavsiye Skoru) nasıl hesaplanır? NPS kaç olmalı? Retrieved 14.01.2020 from https://medium.com/@wiseback/nps-net-tavsiye-skorunas\%C4\%B11-hesaplan\%C4\%B1r-nps-ka\%C3\%A7-olmal\%C4\%B1-3ba3e201bc6f

Zawacki-Richter, O., \& Anderson, T. (2014). Online distance education: Towards a research agenda. Athabasca University Press. 


\section{Yazarlar Hakkında}

\section{Murat DURALí}

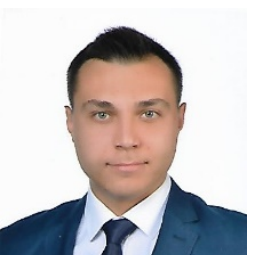

Murat Durali, lisans eğitimini 2015 yılında Anadolu Üniversitesi Uluslararası İlişkiler ve 2017 yılında Erciyes Üniversitesi Havacılık Yönetimi bölümünde tamamlamıştır. 2019 yılı itibari ile Anadolu Üniversitesi Uzaktan Eğitim Anabilim Dalı, Uzaktan Eğitim bölümünde yüksek lisans yapmaktadır. Mehmet Emin Horoz Mesleki ve Teknik Anadolu Lisesi, İstanbul'da Sivil Havacılık branşı öğretmenidir.

Posta adresi: Mehmet Emin Horoz Mesleki ve Teknik Anadolu Lisesi, Avcılar/İstanbul, Türkiye

Eposta: muratdurali@anadolu.edu.tr

\section{Nilgün ÖZDAMAR}

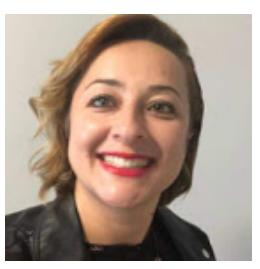

Nilgün Özdamar, Anadolu Üniversitesi Açıköğretim Fakültesi Uzaktan Eğitim Bölümü’nde öğretim üyesi olarak çalışmaktadır. Anadolu Üniversitesi Bilgisayar ve Öğretim Teknolojileri Öğretmenliği lisans eğitimini tamamlamıştır. 2011 yılında “Akademisyenler için Mobil Öğrenme Sisteminin Geliştirilmesi ve Sınanması” konulu doktora tezini bitirmiştir. Mobil öğrenme, Mobil Performans Destek Sistemleri, Kitlesel Çevrimiçi Açık Kurslar (MOOC), MobiMOOC tasarımları, Sürekli/Kesintisiz (Seamless) Öğrenme, Öğretim Tasarımı, Etkinlik Kuramı, Tasarım Tabanlı Araştırma, Kullanılabilirlik, Göz İzleme, Eylem Araştırması, İnsan-Bilgisayar Etkileşimi, Arttırılmış Gerçeklik alanlarında çalışmalar yapmaktadır.

Posta adresi: Anadolu Üniversitesi Açıköğretim Fakültesi, Yunus Emre Kampüsü, Eskişehir, Türkiye

Tel (İş): $\quad$ +902223350580/2445

Eposta: nozdamar@anadolu.edu.tr 